\title{
Effect of environmental and spatial factors on small- sized fish assemblages in a tropical river
}

\author{
Izaias Médice FERNANDES ${ }^{1,2 *}$, Katiele de Jesus SACOMAN ${ }^{1,2}$, José Paulo de FARIAS-NETO ${ }^{1,3}$, Hugmar \\ Pains da SILVA ${ }^{4}$, Jhony VENDRUSCOLO ${ }^{5}$, Luzia da Silva LOURENÇO ${ }^{6}$ \\ ' Universidade Federal de Rondônia, Laboratório de Biodiversidade e Conservação, Av. Norte Sul, Nova Morada,7300, Nova Morada, Rolim de Moura, Rondônia, Brazil \\ 2 Universidade Federal de Rondônia, Programa de Pós-Graduação em Ciências Ambientais, Av. Norte Sul, Nova Morada,7300, Nova Morada, Rolim de Moura, \\ Rondônia, Brazil \\ 3Universidade Federal de Rondônia, Programa Institucional de Bolsas de Iniciação Científica (PIBIC/CNPq), Av. Norte Sul, Nova Morada,7300, Nova Morada, Rolim de \\ Moura, Rondônia, Brazil \\ ${ }^{4}$ Universidade Federal de Mato Grosso, Instituto de Biociências, Laboratório de Citogenética e Genética Animal, Av. Fernando Corrêa da Costa, s/n, Boa Esperança, \\ Cuiabá, Mato Grosso, Brazil \\ ${ }^{5}$ Universidade Federal do Amazonas, Departamento de Engenharia Agrícola e Solos, Av. General Rodrigo Octavio Jordão Ramos, 1200 - Coroado I, Manaus, \\ Amazonas, Brazil \\ ${ }^{6}$ Faculdade Estácio São Paulo de Rondônia, Av. 25 de Agosto, 6961, São Cristovão, Rolim de Moura, Rondônia, Brazil \\ * Corresponding author: biomedice@gmail.com; (D) https://orcid.org/0000-0003-0402-2891
}

\section{ABSTRACT}

The river continuum concept predicts that gradual changes in river geomorphology and hydrology can drive longitudinal changes in aquatic community structure. Accordingly, we evaluated how environmental variables (electrical conductivity, $\mathrm{pH}$, water transparency and water velocity), spatial factors (distance from headwaters and Moran's eigen vector maps - MEMs), and the presence of dams affect small-sized fish assemblages along a 105-km stretch of the upper Branco River, a tributary in the Madeira River, Amazonas Basin, Brazil. Seine-net based collections were carried out at 15 sites up- and downriver from dams during the 2019 dry season. We captured a total of 4,330 individual fish belonging to three orders, nine families and 26 species (and a hybrid individual). Electrical conductivity and $\mathrm{pH}$ were affected by the presence of dams and the distance from headwaters. Species richness and abundance did not vary in response to environmental variables. While species richness showed no significant variation along the sampled river section, abundance showed a negative relationship with distance from headwaters. Species composition varied significantly in response to $\mathrm{pH}$, linear spatial factors and the presence of dams. Our results suggest that change in species composition of small-sized fish assemblages in the upper Branco River occurs due to variation in water characteristics, inherent dispersal limitation, and in response to the presence of dams.

KEYWORDS: distance from headwaters, $\mathrm{pH}$, longitudinal gradient, Amazonas basin

\section{Efeito de fatores ambientais e espaciais sobre assembléias de peixes de pequeno porte em um rio tropical}

\section{RESUMO}

O conceito de rio continuo prediz que mudanças graduais na geomorfologia e hidrologia de um rio podem causar mudanças longitudinais na estrutura de comunidades aquáticas. Nesse contexto, avaliamos como variáveis ambientais (condutividade elétrica, $\mathrm{pH}$, transparência e velocidade da água), fatores espaciais (distância da cabeceira e Moran's eigen vector maps - MEMs) e presença de barragens afetam as assembleias de peixes de pequeno porte ao longo de um trecho de $105 \mathrm{~km}$ do alto Rio Branco, um tributário do Rio Madeira, bacia Amazônica, Brasil. Coletas com rede de arrasto foram realizadas em 15 pontos a jusante e montante de barragens durante a estação seca de 2019. Capturamos um total de 4.330 indivíduos, distribuídos em três ordens, nove famílias e 26 espécies (e um indivíduo híbrido). Condutividade elétrica e $\mathrm{pH}$ foram afetados significativamente pela presença de barragens e pela distância da cabeceira. A riqueza de espécies e a abundância não variaram em função das variáveis ambientais. Ao contrário da riqueza de espécies, que não variou ao longo do trecho amostrado, a abundância apresentou uma relação negativa com a distância da cabeceira. A composição de espécies variou significativamente em resposta ao $\mathrm{pH}$, a fatores espaciais lineares e à presença de barragens. Nossos resultados sugerem que a mudanças na composição de espécies de peixes de pequeno porte no alto Rio Branco ocorre devido à variação em características da água, em função da limitação na dispersão inerente das espécies e em resposta à presença de barragens.

PALAVRAS-CHAVE: distância da cabeceira, $\mathrm{pH}$, gradiente longitudinal, bacia do Rio Amazonas

CITE AS: Fernandes, I.M.; Sacoman, K.J.; Farias-Neto, J.P.; SILVA, H.P.; Vendruscolo, J.; LOURENÇO, L.S. 2021. Effect of environmental and spatial factors on small-sized fish assemblages in a tropical river. Acta Amazonica 51: 129-138. 


\section{INTRODUCTION}

The river continuum concept (Vannote et al. 1980) predicts changes in community structure and ecosystem processes accompanying the gradual changes in geomorphology and hydrology that occur from a river's headwaters to its mouth (Foubert et al. 2018). This vision of a longitudinal gradient has dominated riverine ecological studies in recent years (Benda $e t$ al. 2004). However, this linear perspective does not take into account the presence of natural (waterfalls), anthropogenic (dams) barriers (Ward and Stanford 1995; Torrente-Vilara et al. 2011) and the spatial and temporal dynamics that regulate riverine ecosystem diversity (Altermatt 2013; Tonkin et al. 2017).

Drainage basins are dendritic structures, where rivers function as corridors through which energy, matter and living organisms are transported (Rodriguez-Iturbe et al. 2009). In this structure, headwater sites, being less productive and more isolated, tend to have high endemism, lower species richness and species assemblages that are more structured by environmental variables than assamblages located downstream, which have higher connectivity and are structured by dispersal (Henriques-Silva et al. 2019). In riverine systems, longitudinal connectivity is considered an important aspect as it allows fish and other organisms to disperse through a water course and migrate between upstream and downstream habitats (Fullerton et al. 2010; Branco et al. 2012), especially during the reproductive period (Lucas and Batley 1996).

Among the main factors responsible for the modification of longitudinal connectivity within the dendritic structure of a riverine network, is the construction of dams for reservoir formation and power generation (Fukushima et al. 2007; Fullerton et al. 2010; Winemiller et al. 2016). River damming causes changes in the natural flow of rivers and their associated physical and chemical characteristics (Shao et al. 2019). This is likely to negatively affect organisms not capable of adapting to the new environmental conditions, such as large and migratory fish, and positively impact those species that can take advantage of the new environments, such as smallsized or sedentary fish species with parental care (Agostinho et al. 2016).

In spite of the small-sized fish being dominant in tropical rivers, large-sized migratory fish have received more attention (Fullerton et al. 2010; Torrente-Vilara et al. 2011), as they are more important to commercial and recreational fisheries (Agostinho et al. 2007a; Santos et al. 2018). Small-sized fish are found mainly in marginal regions associated with aquatic vegetation, where a complex habitat structure composed by leaves, stems and roots provides suitable shelter and food (Dias et al. 2011). Besides this, small-sized fish need a small area to complete their life cycle (Agostinho et al. 2007b), and respond to fine-scale environmental variations rather than to spatial factors (Fernandes et al. 2015).
Within this context, this study aimed to evaluate how the structure of small-sized fish assemblages in the Branco River, a tributary in the Madeira River basin in the southwestern Brazilian Amazon, are influenced by: i) environmental factors (electrical conductivity, $\mathrm{pH}$, water transparency and water velocity); ii) linear spatial factors (distance from headwaters and Moran's eigen vector map predictors); and iii) the presence of barriers (dams).

\section{MATERIAL AND METHODS}

\section{Study area}

The Branco River is a tributary of the Madeira River (Figure 1), one of the main tributaries in the Amazonas River basin. The Branco River has an extension of $391.88 \mathrm{~km}$ and a drainage basin of $9,340,615 \mathrm{~km}^{2}$. The regional climate is of the Am type (tropical monsoon), according to the Köppen classification, with an annual precipitation that varies from 1800 to $2300 \mathrm{~mm}$, and average annual temperature between 22 and $26^{\circ} \mathrm{C}$ (Alvares et al. 2014). A dry period lasts from May to October, and the rainy season from November to April (Butt et al. 2011). Due to an altimetric variation of $368 \mathrm{~m}$ between the headwaters and the mouth of the river, rapids and waterfalls are formed, which confer a great potential

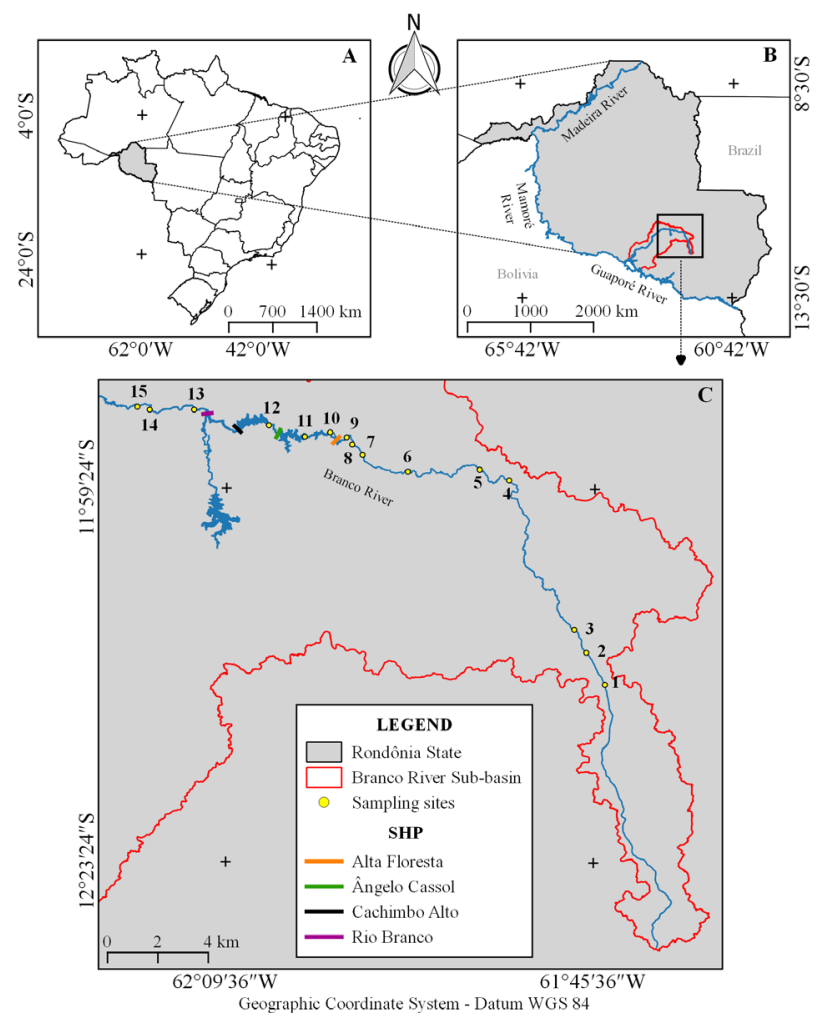

Figure 1. A - Location of the study area in Rondônia state, Brazil; B - Branco River sub-basin, showing the location of sampling sites in the upper Branco River; C - Upper Branco River, showing the location of the 15 sampling sites and four hydroelectric dams. This figure is in color in the electronic version. 
for energy generation (Reis et al. 2020). So far, four small hydroelectric power plants (SHPs) are active along the Branco River (Figure 1), with generation capacity of $5 \mathrm{MW}$ (SHP Alta Floresta, in operation since 2000), 6.9 MW (SHP Rio Branco, in operation since 2005), 3.6 MW (SHP Angelo Cassol, in operation since 2011) and 8.9 MW (SHP Cachimbo Alto, in operation since 2017).

\section{Fish sampling}

Small fish (adults up to $15 \mathrm{~cm}$ in length; Castro and Polaz 2020) samples were collected in June, 2019 (dry season) at 15 sampling sites (P1 - P15) distributed along approximately $105 \mathrm{~km}$ of the upper Branco River (eight upstream from the four dams, four in dam reservoires (one at SPH Alta Floresta, two at SHP Angelo Cassol, and one at SPH Cachimbo Alto) and three downstream from the dams) (Figure 1; Table 1). The dry season was chosen for sampling due to the low flow and reduced water volume of the river, increasing the concentration of fish, and hence sampling efficiency. To collect fish, we used a seine net of $6 \mathrm{~m}$ in length, $2 \mathrm{~m}$ in height, and a mesh size of $2.5 \mathrm{~mm}$ between opposing knots. Each site was sampled once during daylight hours using a standardized effort of three throws. We used only active fishing gear because small fish are mostly sedentary and do not conduct reproductive migrations, so that they are found in the same environment throughout the year and are not efficiently sampled by passive fishing gear. At all sites, we sampled close to the river margin, in the presence of aquatic vegetation and on sandy substrates (Lapointe et al. 2011).

Captured fish were anesthetized using eugenol $(0.20$ $\mathrm{mL}$, equivalent to $200 \mathrm{mg}$, of clove oil per $500 \mathrm{~mL}$ of water;
Fernandes et al. 2017), fixed in $10 \%$ formalin solution, preserved in $70 \%$ alcohol, identified and later deposited in the ichthyological collection of Universidade Federal de Mato Grosso (UFMT), Cuiabá, Mato Grosso state, Brazil. Fish identification was carried out with the help of regional keys (Queiroz et al. 2013), and articles describing specific species. Collection was authorized by SISBIO license \# 57920-2 issued by the Brazilian national environmental agency (Instituto Chico Mendes de Conservaçáo da Biodiversidade - ICMBio) and by the Ethics Committee on Animal Use of Universidade Federal de Rondonônia (protocol \# 001/2021 - CEUA/UNIR).

\section{Environmental factors}

Geographical coordinates of each sampling location were taken using GPS devices (Datum WGS84). $\mathrm{pH}$, and electrical conductivity $\left(\mu \mathrm{S} \mathrm{cm}^{-1}\right)$ were measured in situ with an AK88 multiparameter probe inserted to an approximate depth of $20 \mathrm{~cm}$. Water transparency was measured with a Secchi disk and graduated cord. Water velocity $\left(\mathrm{m} \mathrm{s}^{-1}\right)$ was measured by calculating the time a small styrofoam ball took to float from one end to the other of a 50-cm wooden rod (average of three measures). Water temperature and oxygen concentration were measured, but were subsequently discarded due to a technical problem with the AK88 multiparameter probe sensor.

\section{Spatial factors}

The distance from headwaters was estimated as the distance from each sampling site along the river to the most distant point in the headwater region considered as the source of the Branco River. We also used Moran's eigen vector maps

Table 1. Sampling sites, environmental variables and spatial factors measured for each of 15 sampling sites of small-sized fish assemblages in the upper Branco River, Madeira River basin, Brazilian Amazon.

\begin{tabular}{|c|c|c|c|c|c|c|c|c|c|}
\hline \multirow[b]{2}{*}{ Sampling site } & \multirow[b]{2}{*}{ Latitude } & \multirow[b]{2}{*}{ Longitude } & \multirow[b]{2}{*}{ Regions } & \multicolumn{4}{|c|}{ Environmental variables } & \multicolumn{2}{|c|}{ Spatial factors } \\
\hline & & & & $\begin{array}{c}\text { Electrical } \\
\text { conductivity } \\
\left(\mu \mathrm{Scm}^{-1}\right)\end{array}$ & $\mathrm{pH}$ & $\begin{array}{c}\text { Transparency } \\
(\mathrm{cm})\end{array}$ & $\begin{array}{l}\text { Water } \\
\text { velocity } \\
\left(\mathrm{m} \mathrm{s}^{-1}\right)\end{array}$ & $\begin{array}{l}\text { Distance from } \\
\text { headwaters } \\
(\mathrm{km})\end{array}$ & MEM2 \\
\hline P1 & $12^{\circ} 11^{\prime} 57.24^{\prime \prime} \mathrm{S}$ & $61^{\circ} 44^{\prime} 53.78^{\prime \prime} \mathrm{W}$ & Upstream & 14.3 & 7.2 & 79 & 0 & 40.400 & -0.2782 \\
\hline P2 & $12^{\circ} 9^{\prime} 54.27^{\prime \prime S}$ & $61^{\circ} 46^{\prime} 6.11^{\prime \prime} \mathrm{W}$ & Upstream & 8.8 & 6.48 & 160 & 0.13 & 45.239 & 0.2396 \\
\hline P3 & $12^{\circ} 8^{\prime} 25.14^{\prime \prime S}$ & $61^{\circ} 46^{\prime} 53.83^{\prime \prime} \mathrm{W}$ & Upstream & 11.1 & 6.94 & 115 & 0.08 & 50.493 & 0.0350 \\
\hline P4 & $11^{\circ} 58^{\prime} 51.53^{\prime \prime S}$ & $61^{\circ} 51^{\prime} 11.95^{\prime \prime} \mathrm{W}$ & Upstream & 35.7 & 7.02 & 82 & 0.07 & 79.928 & -0.0017 \\
\hline P5 & $11^{\circ} 58^{\prime} 9.71^{\prime \prime S}$ & $61^{\circ} 53^{\prime} 6.85^{\prime \prime} \mathrm{W}$ & Upstream & 34.3 & 7.19 & 58 & 0.12 & 86.377 & 0.0084 \\
\hline P6 & $11^{\circ} 58^{\prime} 18.41^{\prime \prime S}$ & $61^{\circ} 57^{\prime} 47.80^{\prime \prime} \mathrm{W}$ & Upstream & 41.11 & 7.3 & 67 & 0.17 & 100.804 & -0.0074 \\
\hline P7 & $11^{\circ} 57^{\prime} 13.68^{\prime \prime S}$ & $62^{\circ} 0^{\prime} 44.98^{\prime \prime} \mathrm{W}$ & Upstream & 43.9 & 7.3 & 50 & 0.5 & 108.731 & -0.0384 \\
\hline P8 & $11^{\circ} 56^{\prime} 35.35^{\prime \prime S}$ & $62^{\circ} 1^{\prime} 25.88^{\prime \prime} \mathrm{W}$ & Upstream & 44.5 & 7.54 & 62 & 0.15 & 110.684 & 0.2051 \\
\hline P9 & $11^{\circ} 56^{\prime} 0.20^{\prime \prime} \mathrm{S}$ & $62^{\circ} 1^{\prime} 38.14^{\prime \prime} \mathrm{W}$ & Reservoir & 50.5 & 7.61 & 66 & 0.12 & 112.062 & -0.1690 \\
\hline P10 & $11^{\circ} 55^{\prime} 49.23^{\prime \prime S}$ & $62^{\circ} 2^{\prime} 52.30^{\prime \prime} \mathrm{W}$ & Reservoir & 46.4 & 7.75 & 71 & 0 & 115.457 & -0.0018 \\
\hline P11 & $11^{\circ} 56^{\prime} 9.86^{\prime \prime S}$ & $62^{\circ} 4^{\prime} 28.26^{\prime \prime} \mathrm{W}$ & Reservoir & 48.1 & 7.66 & 88 & 0 & 118.929 & 0.6238 \\
\hline P12 & $11^{\circ} 55^{\prime} 22.47^{\prime \prime S}$ & $62^{\circ} 6^{\prime} 50.80^{\prime \prime} \mathrm{W}$ & Reservoir & 50.4 & 7.71 & 101 & 0.13 & 124.611 & -0.6343 \\
\hline P13 & $11^{\circ} 54^{\prime} 22.31^{\prime \prime S}$ & $62^{\circ} 11^{\prime} 44.33^{\prime \prime} \mathrm{W}$ & Downstream & 50.2 & 7.53 & 96 & 0.1 & 136.526 & 0.0048 \\
\hline P14 & $11^{\circ} 54^{\prime} 34.70^{\prime \prime S}$ & $62^{\circ} 14^{\prime} 12.32^{\prime \prime} \mathrm{W}$ & Downstream & 50.2 & 7.72 & 84 & 0.3 & 142.209 & 0.0023 \\
\hline P15 & $11^{\circ} 54^{\prime} 12.90^{\prime \prime S}$ & $62^{\circ} 15^{\prime} 29.40^{\prime \prime} \mathrm{W}$ & Downstream & 51.2 & 7.6 & 102 & 0.12 & 145.602 & 0.0116 \\
\hline
\end{tabular}


- MEMs (Borcard et al., 2004), which are spatial predictors generated using a topological distance matrix (distances among all the sampling sites along the river), to assess the magnitude of fish dispersal along the water course (Altermatt 2013). To build the spatial predictors, the "pcnm" function of the vegan package (Oksanen et al. 2019) from the R Program was used. This procedure resulted in eight spatial predictors ranging from broad (MEM1) to fine scale (MEM8), representing both the effect of dispersal limitation and variables that were not measured but are spatially structured (Peres-Neto and Legendre 2010; Fernandes et al. 2014).

\section{Data analysis}

To assess the effect of dam presence, the data were grouped in three regions: sites dowstream from the dams, sites within reservoires and sites upstream from the dams. Water electrical conductivity, $\mathrm{pH}$, transparency and velocity were compared between regions with a Kruskal-Wallis analysis, as the data were not normally distributed (according to a Shapiro-Wilk test) and did not show homogeneous variance (according to a Bartlett test) (Sokal and Rohlf 1995). When test results were significant $(\mathrm{p}<0.05)$, the post hoc test proposed by Siegel and Castellan (1988) was used to determine in which region the environmental variables differed significantly. This analysis was made using the "kruskalmc" function of the pgirmess package (Giraudoux et al. 2018). The effect of distance from headwaters on environmental variables was assessed using linear regression (Zar 1999). Extent of collinearity among the variables was assessed using variance inflation factors (VIF). When the variable showed a VIF value larger than 3, it was dropped from the multiple regression (Zuur et al. 2010). Electrical conductivity showed a high positive correlation with $\mathrm{pH}(\mathrm{r}=0.87)$, and a negative correlation with water transparency $(\mathrm{r}=-0.51)$, and $\mathrm{pH}$ showed a negativie correlation with water transparency $(\mathrm{r}=-0.51)$. Thus, both electrical conductivity and $\mathrm{pH}$ showed VIF $>3$ and were removed from the analysis.

The effect of dam presence on species richness and abundance was evaluated using Kruskal-Wallis tests, while the effect of the continuous variables transparency, water velocity, and distance from headwaters was assessed with a multiple regression.

To evaluate the effect of environmental factors [E] (electrical conductivity, $\mathrm{pH}$, transparency and water velocity), and spatial factors $[\mathrm{S}]$ (distance from headwaters and Moran's eigen vector maps - MEMs) on species composition, an analysis of variance partition was used (Peres-Neto et al. 2006). Variance partition is based on partial redundancy analysis (pRDA), and allows reduction of the explained variance percentage $\left(\mathrm{r}^{2}\right)$ for each predictor variable (Borcard et al. 1992; Legendre 1993; Legendre et al. 2005; Peres-Neto and Legendre 2010). The environmental and spatial factors were selected using the "forward.sel" function of the adespatial package (Dray et al. 2020).

To evaluate the effect of dam presence on species composition, a non-parametric multivariate analysis of variance (PERMANOVA) was used (Anderson 2001). The distance matrix between sites was calculated using BrayCurtis distances (Legendre and Legendre 2012; Clarke and Warwick 2014), after species composition data was transformed using the Hellinger method (Legendre and Gallagher 2001). The statistical test used for PERMANOVA is a pseudo-F, and is calculated directly from any symmetric distance or dissimilarity matrix, with $\mathrm{P}$ values calculated for 999 permutations. The analysis was made using the "pairwise. perm.manova" function from the RVAideMemoire package (Hervé 2020). All analyses were performed in the R Program environment (R Core Team 2020).

\section{RESULTS}

\section{Ichthyofauna}

A total of 4,330 individuals were captured, distributed among three orders, nine families and 26 species (Table 2). The only species that fell outside the small-fish size criterion was Hoplias malabaricus, that has adults that can reach up to $65 \mathrm{~cm}$. The dominant order was Characiformes, with 22 species, followed by Siluriformes and Cichliformes, with two species each. Serrapinnus cf. microdon, with 2,459 individuals (56.8\%), Serrapinnus micropterus, with 804 (18.6\%), Moenkhausia sp. 2, with 265 (6.1\%) and Bryconops cf. caudomaculatus, with 211 (4.9\%) were the most abundant species (Table 2). A sole hybrid individual (locally known as jundiara) resulting from a cross between Leiarius marmoratus and Pseudoplatystoma punctifer was captured in the SHP Ângelo Cassol reservoir (P10 in Table 2 and Figure 1).

Fish abundance varied from 12 individuals at P11 to 762 at P2 (Table 1), with an mean of 288 individuals per site. On average, 4.4 species were captured per sampling site. The highest species richness $(S=7)$ was found at P10, and the lowest at P4 $(\mathrm{S}=2)$.

\section{Environmental characteristics}

The water in the studied stretch of the Branco River was relatively alkaline with low electrical conductivity (Table 1). Significantly higher values for these variables were found in the reservoirs and in the downstream region (Table 3 ). In the three regions, the water was transparent and with low velocity (Table 1), and the two variables did not differ significantly among the regions (Table 3). Conductivity $\left(\mathrm{r}^{2}=0.90, \mathrm{p}<\right.$ 0.001 ; Figure 2) and $\mathrm{pH}\left(\mathrm{r}^{2}=0.68, \mathrm{p}<0.001\right.$; Figure 3$)$ increased significantly with the distance from the headwaters. Transparency $\left(\mathrm{r}^{2}=0.03, \mathrm{p}=0.24\right)$ and water velocity $\left(\mathrm{r}^{2}=\right.$ $0.01, \mathrm{p}=0.34$ ) did not show any relationship with distance from the headwaters. 
Table 2. List of small-sized fish species captured at 15 sampling sites along the upper Branco River, Madeira River basin, in the southwestern Brazilian Amazon. Values are the number of individuals captured at each site and overall (TTL).

\begin{tabular}{llllllllllllllllll}
\hline Order/Family/Species & P1 & P2 & P3 & P4 & P5 & P6 & P7 & P8 & P9 & P10 & P11 & P12 & P13 & P14 & P15 & TTL & Voucher \\
\hline CHARACIFORMES & & & & &
\end{tabular}

\section{Curimatidae}

Steindachnerina guentheri (Eigenmann \&

Eigenmann, 1889)

\section{Crenuchidae}

Characidium zebra Eigenmann, 1909

$\begin{array}{lllllllllllllllll}0 & 0 & 0 & 0 & 0 & 0 & 0 & 1 & 1 & 2 & 0 & 0 & 0 & 0 & 0 & 4 & \text { CPUFMT6900 }\end{array}$

\section{Iguanodectidae}

Bryconops cf. caudomaculatus (Günther, 1864)

Bryconops cf. giacopinii (Fernández-Yépez, 1950)

$\begin{array}{ccccccccccccccccc}60 & 0 & 142 & 0 & 0 & 7 & 2 & 0 & 0 & 0 & 0 & 0 & 0 & 0 & 0 & 211 & \text { CPUFMT6892 } \\ 0 & 116 & 0 & 0 & 0 & 0 & 0 & 29 & 0 & 13 & 0 & 0 & 0 & 0 & 0 & 158 & \text { CPUFMT6903 }\end{array}$

\section{Characidae}

Aphyocharax sp.

Astyanax sp.

Hemigrammus lunatus Durbin, 1918

Hemigrammus stictus (Durbin, 1909)

Knodus cf. heteresthes (Eigenmann, 1908)

Knodus cf. orteguasae (Fowler, 1943)

Knodus cf. smithi (Fowler, 1913)

Moenkhausia sp.

Moenkhausia sp. 1

Moenkhausia sp. 2

Moenkhausia oligolepis (Günther, 1864)

Odontostilbe nareuda Bührnheim \& Malabarba,

2006

Roeboides affinis (Günther, 1868)

Serrapinnus cf. microdon (Eigenmann, 1915)

Serrapinnus cf. notomelas (Eigenmann, 1915)

Serrapinnus micropterus (Eigenmann, 1907)

$\begin{array}{ccccccccccccccccc}0 & 0 & 0 & 0 & 0 & 0 & 0 & 0 & 0 & 0 & 0 & 0 & 18 & 63 & 20 & 101 & \text { CPUFMT6887 } \\ 0 & 0 & 0 & 0 & 0 & 0 & 0 & 0 & 0 & 0 & 8 & 0 & 0 & 0 & 0 & 8 & \text { CPUFMT6897 } \\ 0 & 0 & 0 & 0 & 0 & 0 & 0 & 0 & 0 & 0 & 0 & 0 & 0 & 0 & 1 & 1 & \text { CPUFMT6907 } \\ & & & & & & & & & & & & & & & 1 & \text { CPUFMT6889 } \\ 0 & 0 & 19 & 29 & 0 & 0 & 0 & 0 & 0 & 10 & 0 & 0 & 0 & 0 & 0 & 58 & \text { CPUFMT6893 } \\ 0 & 0 & 0 & 0 & 0 & 3 & 52 & 0 & 0 & 0 & 0 & 0 & 0 & 3 & 0 & 58 & \text { CPUFMT6899 } \\ 0 & 0 & 0 & 0 & 0 & 0 & 0 & 1 & 0 & 0 & 0 & 0 & 0 & 0 & 0 & 1 & \text { CPUFMT6905 } \\ 0 & 0 & 0 & 0 & 0 & 0 & 0 & 0 & 0 & 0 & 0 & 0 & 0 & 33 & 0 & 33 & \text { CPUFMT6888 } \\ 0 & 0 & 0 & 0 & 0 & 0 & 0 & 0 & 0 & 0 & 0 & 0 & 0 & 5 & 0 & 5 & \text { CPUFMT6890 } \\ 0 & 0 & 0 & 0 & 0 & 0 & 0 & 0 & 0 & 36 & 0 & 228 & 1 & 0 & 0 & 256 & \text { CPUFMT6901 } \\ 0 & 0 & 0 & 0 & 0 & 0 & 0 & 0 & 0 & 0 & 0 & 0 & 0 & 0 & 1 & 1 & \text { CPUFMT6906 } \\ 0 & 0 & 0 & 0 & 0 & 0 & 0 & 0 & 0 & 1 & 0 & 0 & 12 & 11 & 5 & 29 & \text { CPUFMT6891 } \\ 0 & 0 & 0 & 0 & 0 & 0 & 0 & 0 & 0 & 0 & 0 & 0 & 0 & 0 & 1 & 1 & \text { CPUFMT6908 } \\ 0 & 631 & 371 & 393 & 491 & 531 & 41 & 1 & 0 & 0 & 0 & 0 & 0 & 0 & 0 & 2459 & \text { CPUFMT6895 } \\ 0 & 0 & 0 & 0 & 0 & 0 & 0 & 0 & 0 & 0 & 1 & 0 & 0 & 0 & 0 & 1 & \text { CPUFMT6898 } \\ 695 & 0 & 0 & 0 & 0 & 0 & 0 & 0 & 105 & 0 & 0 & 1 & 3 & 0 & 0 & 804 & \text { CPUFMT6885 }\end{array}$

\section{Acestrorhynchidae}

Acestrorhynchus falcatus (Bloch, 1794)

\section{Erythrinidae}

Hoplias malabaricus (Bloch, 1794)

\section{CICHLIFORMES}

\section{Cichlidae}

Crenicichla lepidota Heckel, 1840

Satanoperca curupira Ota, Kullander, Deprá, da Graça \& Pavanelli, 2018

SILURIFORMES

\section{Heptapteridae}

Pimelodella boliviana Eigenmann, 1917

$\begin{array}{lllllllllllllllll}0 & 0 & 0 & 0 & 0 & 18 & 0 & 0 & 0 & 0 & 0 & 0 & 0 & 0 & 0 & 18 & \text { (PUFMT6904 }\end{array}$

\section{Loricariidae}

Rineloricaria sp.

Total abundance 
Table 3. Variation of limnological variables by sampling region along the upper Branco River, Madeira River basin, in the southwestern Brazilian Amazon. Values are the median followed by the range.

\begin{tabular}{|c|c|c|c|c|c|}
\hline Limnological variable & Upstream & Reservoir & Downstream & $x^{2}$ & $p$-value \\
\hline Electrical conductivity $\left(\mu \mathrm{S} \mathrm{cm}^{-1}\right)$ & $35.0(8.8-44.5)^{\mathrm{a}}$ & $49.2(46.4-50.5)^{b}$ & $50.2(50.2-51.2)^{b}$ & 10.6 & 0.004 \\
\hline $\mathrm{pH}$ & $7.1(6.4-7.5)^{\mathrm{a}}$ & $7.6^{b}(7.6-7.7)^{b}$ & $7.6(7.5-7.7)^{\mathrm{ab}}$ & 10.1 & 0.006 \\
\hline Transparency (cm) & $73.0(50-160)$ & $79.5(66-101)$ & $96.0(84-102)$ & 1.8 & 0.395 \\
\hline Water velocity $\left(\mathrm{m} \mathrm{s}^{-1}\right)$ & $0.12(0.0-0.50)$ & $0.06(0.0-0.13)$ & $0.12(0.1-0.3)$ & 1.6 & 0.447 \\
\hline
\end{tabular}

Different superscript letters in a line indicate significant differences according to a Kruskal-Wallis test and a Tukey post-hoc test.



Figure 2. Relationship between electrical conductivity and distance from headwaters along the upper Branco River, Rondônia state, Brazil.

\section{Effect of environmental and spatial factors on fish assemblages}

Fish abundance (Kruskal-Wallis $X^{2}=6.02, \mathrm{p}=0.05$ ) and species richness (Kruskal-Wallis $X^{2}=6.04, \mathrm{p}=0.05$ ) did not vary significantly between the three regions, and were not significantly related to water transparency (abundance: $\mathrm{r}^{2}=$ $0.52, \mathrm{p}=0.98$; species richness: $\mathrm{r}^{2}=-0.004, \mathrm{p}=0.66$ ), or water velocity (abundance: $\mathrm{r}^{2}=0.52, \mathrm{p}=0.32$; species richness: $\mathrm{r}^{2}$ $=-0.004, \mathrm{p}=0.38$ ). Fish abundance showed a significantly negative relationship with distance from headwaters $\left(\mathrm{r}^{2}=\right.$ $0.52, p=0.001$; Figure 4), while species richness showed no significant variation along the longitudinal gradient $\left(\mathrm{r}^{2}=\right.$ $-0.004, \mathrm{p}=0.41)$.

Of the environmental factors, only $\mathrm{pH}$ was selected using the "forward.sel" function, while, of the spatial factors, only MEM2 was selected. Accordingly, both MEM2 and distance from headwaters were used as spatial predictors. Variance partitioning ( $\mathrm{pRDA}$ ) indicated that environmental factors [E] contributed $12 \%$ of the variance in species composition $\left(r^{2}\right.$ adjusted $\left.=0.12, p=0.003\right)$, spatial factors $[S]$ contributed $15 \%$ of the variance $\left(r^{2}\right.$ adjusted $\left.=0.15, p=0.001\right)$ while $3 \%$ of the variance in species composition was shared between environmental and spatial factors $[E \mid S]$, and $70 \%$ of the

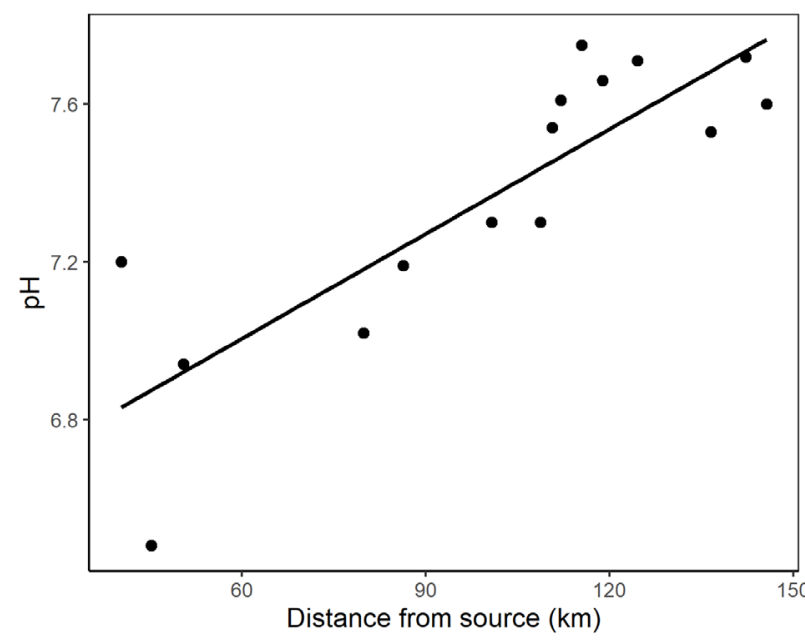

Figure 3. Relationship between $\mathrm{pH}$ and distance from headwaters along the upper Branco River, Rondônia state, Brazil.

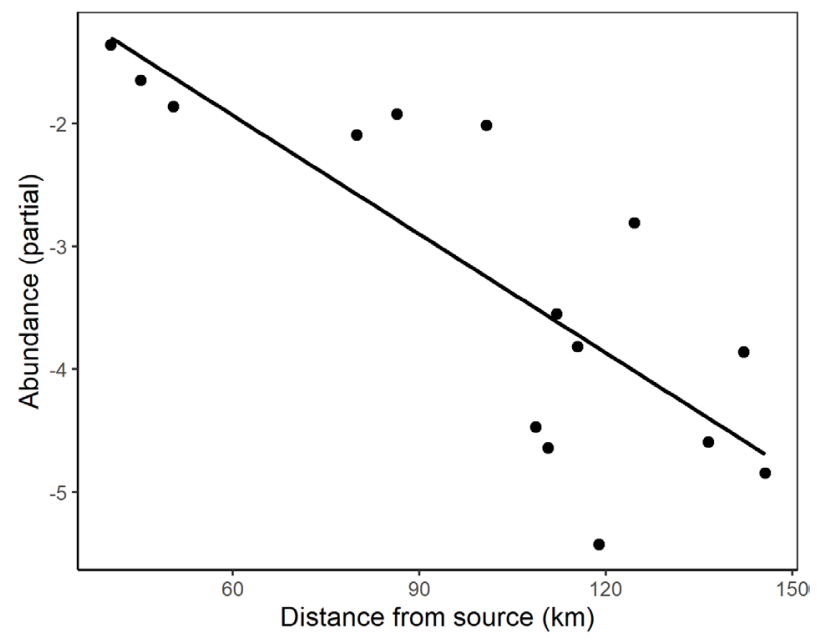

Figure 4. Relationship between fish abundance and distance from headwaters along the upper Branco River, Rondônia state, Brazil.

variance was not explained by any of the variables considered in this study (Residual $=0.70$ ). Species composition varied significantly between regions (PERMANOVA: $\mathrm{r}^{2}=0.44, \mathrm{~F}$ $=4.72, \mathrm{p}=0.001 ; \mathrm{p}<0.01$ for all pairwise comparisons). 


\section{DISCUSSION}

\section{Ichthyofauna}

The dominance of members of the order Characiformes in our samples is in accordance with other studies carried out in the Amazon (Lowe-McConnel 1999; Torrente-Vilara et al. 2011), and can be explained by the dominance of this order in the Amazon region (there are approximately 1,063 known valid species of Characiformes in this region; Dagosta and De Pinna 2019). The presence of one hybrid individual of jundiara in the Branco River is probably the results of the rupture of fish ponds, which are built close to the banks of rivers or through the damming of small watercourses. The impact of jundiaras on aquatic ecosystms is still uncertain, however, their high growth rates (Barros et al. 2020) and morphological, ecological and reproductive similarity to native species (Nobile et al. 2020) can facilitate their settlement and may pose a threat to native species. This the first record of the hybrid jundiara captured in nature in the Amazon basin.

\section{Environmental characteristics}

The highest electrical conductivity and $\mathrm{pH}$ values were found in the regions furthest from the headwaters, in the reservoirs and in the downstream region. Electrical conductivity and $\mathrm{pH}$ quantify the volume of total ions dissolved in the water and vary depending on the rock type forming a basin's soil, the amount of organic matter, and the rate of oxygen input from photosynthesis (Niemistö et al. 2011; Hayashi et al. 2012). Additionally, the concentration of nutrients, sediment, pollutants and organic matter increases towards the river mouth, so that sampling sites located in downstream regions show higher nutrient concentrations (Swanson et al. 2006; Altermatt 2013; Forsberg et al. 2017) and, consequently, higher electrical conductivity.

The uppermost sampling locations (P1 to P3) lie on the Casa Branca Formation, composed mainly of micaceous sandstones, while sites P4 and P5 lie on the São Felipe Formation, formed by gneiss and granite subtypes (Quadros and Rizzotto 2007). These rocks are acidic, and, when weathered, tend to lower soil pH (Scandolara et al. 1999). Sites P6 to P15 were located on the Rio Branco Formation, which has a predominance of metagabro and amphibolites, basic rocks, which, when weathered, tend to raise soil $\mathrm{pH}$ (Scandolara et al. 1999). Thus, the downstream increase in $\mathrm{pH}$ and electrical contuctivity is likely linked to the input of nutrients from agricultural effluents and primary productivity mediated by the geological formations underlying the study area.

\section{Effect of environmental and spatial factors on fish assemblages}

Although some studies have shown that within-assemblage abundance increases in downstream direction (Henriques-
Silva et al. 2019; Borthagaray et al. 2020), we found a negative relationship between abundance and distance from headwaters. This was due to that three of the most abundant species (Serrapinnus cf. microdon, Serrapinnus micropterus and Bryconops cf. caudomaculatus), which accounted for $80.3 \%$ of catches, dominanted in the headwater sites, probably owing to higher abundance of subaquatic vegetation at these sites, favouring higher fish density. Due to their small body size, these species have low dispersal capacity and often live in association with aquatic plants, where they find food resources and protection from predators (Petry et al. 2003; Agostinho et al. 2007b).

The spatial distribution of small-sized fish assemblages in the Branco River was influenced by environmental filters, dispersal limitation, distance from headwaters and presence of dams. Effects of $\mathrm{pH}$ on fish-assemblage composition has been documented in both tropical and temperate regions (Rahel 1984; Lourenço et al. 2012). Water with high pH (basic water) or low $\mathrm{pH}$ (acidic water) can affect gill function (Wurts and Durborow 1992) and, consequently, gas exchange and osmoregulation, impairing biological process (Rahel 1984). Despite having explained only $12 \%$ of the variance in species composition, $\mathrm{pH}$ was the most relevant of the evaluated environmental filters to influence small-fish species composition in the upper Branco River.

The effect of the spatial factor (MEM2) may be related to the limited dispersal capacity of small-sized fish species at larger scales (Griffiths 2006; Bie et al. 2012; Henriques-Silva et al. 2013; Fernandes et al. 2014). Small fish are mostly short-distance migrants, and respond mainly to fine-scale environmental variations like water depth and habitat structure (Lamouroux et al. 1999; Fernandes et al. 2015). Likewise, the effect of the distance from headwaters also points to limited dispersal capacity, as predicted by the network position hypothesis (Henriques-Silva et al. 2019; Borthagaray et al. 2020). Environmental and spatial factors explained only $30 \%$ of the variation in our data, which indicates that important variables, such as functional connectivity, and ecological interactions, such as competition, known to be important in regulating composition and structure of local assemblages (Cadotte and Tucker 2017) were not considered.

Some studies have shown that hydroelectric dams alter the characteristics of the aquatic environment (Forsberg et al. 2017) and reduce up- and downstream connectivity, further limiting the large-scale dispersal of fish (Falke and Gido 2006; Barbosa et al. 2015), resulting in changes in fish assemblage structure (Torrente-Vilara et al. 2011; Vitorino Júnior et al. 2016; Cella-Ribeiro et al. 2017), and reductions in fishery stocks (Santos et al. 2018). Previous studies have generally focused on species with larger body size, which are more likely to be migratory and rheophilic (Couto et al. 2021), unlike the small-sized fish considered in our study, which are mostly 
short-distance migrants (Castro and Polaz 2020). Our results indicate that the presence of dams also affects small-sized margin-dwelling fish assemblages. However, the unbalanced sampling design between the three regions, with a higher number of sites and range of distances among sites in the upstream region, may have influenced species composition, richness and abundance estimates.

\section{CONCLUSIONS}

The small-sized fish assemblage from the upper Branco River was dominated by order Characiformes and the variance in species composition was explained mainly by environmental $(\mathrm{pH})$ and spatial factors (MEM2 and distance from headwaters), as well as the presence of dams. Environmental and spatial factors explained $30 \%$ of the variation in our data, which indicates that important variables were not mensured. Future studies that assess the longitudinal gradient in the riverine landscape in the Amazon basin should take into account the effect of other environmental variables and further evaluate the effect of the alterations in the natural river dynamics on the connectivity in small-sized fish species.

\section{ACKNOWLEDGMENTS}

We thank Fundação Rondônia de Amparo ao Desenvolvimento das Açóes Científicas e Tecnológicas e de Pesquisa do Estado de Rondônia - FAPERO (proc. \# 01.1331.00032.031/2015) for financial support, and Elaine Almeida Delarmelinda Honoré for geological information on the study area. Adrian Barnett helped with the English.

\section{REFERENCES}

Agostinho, A.A.; Pelicice, F.M.; Petry, A.C.; Gomes, L.C.; Júlio Jr, H.F. 2007a. Fish diversity in the upper Paraná River basin: habitats, fisheries, management and conservation. Aquatic Ecosystem Health \& Management, 10: 174-186.

Agostinho, A.A.; Thomaz, S.M.; Gomes, L.C.; Baltar, S.L. 2007b. Influence of the macrophyte Eichhornia azurea on fish assemblage of the Upper Paraná River floodplain (Brazil). Aquatic Ecology, 41: 611-619.

Agostinho, A.A.; Gomes, L.C.; Santos, N.C.; Ortega, J.C.; Pelicice, F.M. 2016. Fish assemblages in Neotropical reservoirs: Colonization patterns, impacts and management. Fisheries Research, 173: 26-36.

Altermatt, F. 2013. Diversity in riverine metacommunities: a network perspective. Aquatic Ecology, 47: 365-377.

Alvares, C.A.; Stape, J.L.; Sentelhas, P.C.; de Moraes, G.; Leonardo, J.; Sparovek, G. 2014. Köppen's climate classification map for Brazil. Meteorologische Zeitschrift, 22: 711-728

Anderson, M.J.; Ellingsen, K.E; McArdle, B.H. 2006 Multivariate dispersion as a measure of beta diversity. Ecology Letters, 9: 683-693.

Barbosa, T.A.P.; Benone, N.L.; Begot, T.O.R.; Gonçalves, A.; Sousa, L.; Giarrizzo, T.; Juen, L.; Montag, L.F.D.A. 2015. Effect of waterfalls and the flood pulse on the structure of fish assemblages of the middle Xingu River in the eastern Amazon basin. Brazilian Journal of Biology, 75: 78-94.

Barros, R.P.; Luz, J.R.; de Souza Ramos, A.P.; Costa, D.S.; Braga, L.G.T. 2020. Crude protein requirements in feeding for hybrid jundiara (Pseudoplatystoma fasciatum x Leiarius marmoratus). Research, Society and Development, 9: e978986866-e978986866.

Benda, L.E.E.; Poff, N.L.; Miller, D.; Dunne, T.; Reeves, G.; Pess, G.; Pollock, M. 2004. The network dynamics hypothesis: how channel networks structure riverine habitats. BioScience, 54: 413-427.

Bie, T.; De Meester, L.; Brendonck, L.; Martens, K.; Goddeeris, B.; Ercken, D.; Hampel, H.; Denys, L.; Vanhecke, L.; Van der Gucht, K.; Van Wichelen, J. 2012. Body size and dispersal mode as key traits determining metacommunity structure of aquatic organisms. Ecology Letters, 15: 740-747.

Borcard, D.; Legendre, P.; Drapeau, P. 1992. Partialling out the spatial component of ecological variation. Ecology, 73: 10451055.

Borcard, D.; Legendre, P.; Avois-Jacquet, C.; Tuomisto, H. 2004. Dissecting the spatial structure of ecological data at multiple scales. Ecology, 85: 1826-1832.

Borthagaray, A.I.; Teixeira de Mello, F.; Tesitore, G.; Ortiz, E.; Illarze, M.; Pinelli, V.; et al. 2020. Community isolation drives lower fish biomass and species richness, but higher functional evenness, in a river metacommunity. Freshwater Biology, 65: 2081-2095.

Branco, P.; Segurado, P.; Santos, J.M.; Pinheiro, P.; Ferreira, M.T. 2012. Does longitudinal connectivity loss affect the distribution of freshwater fish?. Ecological Engineering, 48: 70-78.

Butt, N.; De Oliveira, P.A.; Costa, M.H. 2011. Evidence that deforestation affects the onset of the rainy season in Rondonia, Brazil. Journal of Geophysical Research: Atmospheres, 116: D11.

Cadotte, M.W.; Tucker, C.M. 2017. Should environmental filtering be abandoned?. Trends in Ecology \& Evolution, 32: 429-437.

Castro, R.; Polaz, C.N. 2020. Small-sized fish: the largest and most threatened portion of the megadiverse neotropical freshwater fish fauna. Biota Neotropica, 20: e20180683

Clarke, K.R.; Warwick, W.M. 2014. Change in Marine Communities: An Approach to Statistical Analysis and Interpretation. Primer-E Ltd, Plymouth. 256 p.

Cella-Ribeiro, A.; Doria, C.R.C.; Dutka-Gianelli, J.; Alves, H.; Torrente-Vilara, G. 2017. Temporal fish community responses to two cascade run-of-river dams in the Madeira River, Amazon basin. Ecohydrology, 10: e1889.

Couto, T.B.; Messager, M.L.; Olden, J.D. 2021. Safeguarding migratory fish via strategic planning of future small hydropower in Brazil. Nature Sustainability, 4: 1-8. doi.org/10.1038/s41893020-00665-4

Dagosta, F.C.; De Pinna, M. 2019. The fishes of the Amazon: distribution and biogeographical patterns, with a comprehensive list of species. Bulletin of the American Museum of Natural History, 2019: 1-163.

Dias, M.S.; Toledo, J.J.; Jardim, M.M.; Figueiredo, F.O.G.; Oliveira Cordeiro, C.L.; Gomes, A.C.S.; Zuanon, J. 2011. Congruence 
between fish and plant assemblages in drifting macrophyte rafts in Central Amazonia. Hydrobiologia, 661: 457-461.

Dray, S.; Blanchet, G.; Borcard, D.;Guenard, G.; Jombart, T.; Larocque, G.; Legendre, P.; Madi, N.; Wagner, H.H; Dray, M.S. 2020. Package 'adespatial'. R package version.

Falke, J.A.; Gido, K.B. 2006. Spatial effects of reservoirs on fish assemblages in Great Plains streams in Kansas, USA. River Research and Applications, 22: 55-68.

Fernandes, I.M.; Lourenço, L.S.; Ota, R.P.; Moreira, M.M.M.; Zawadzki, C.H. 2013. Effects of local and regional factors on the fish assemblage structure in Meridional Amazonian streams. Environmental Biology of Fish, 96: 837-848.

Fernandes, I.M.; Henriques-Silva, R.; Penha, J.; Zuanon, J.; Peres-Neto, P.R. 2014. Spatiotemporal dynamics in a seasonal metacommunity structure is predictable: the case of floodplainfish communities. Ecography, 37: 464-475.

Fernandes, I.; Penha, J.; Zuanon, J. 2015. Size-dependent response of tropical wetland fish communities to changes in vegetation cover and habitat connectivity. Landscape ecology, 30: 1421-1434.

Fernandes, I.M.; Bastos, Y.F.; Barreto, D.S.; Lourenço, L.S.; Penha, J.M. 2017. The efficacy of clove oil as an anaesthetic and in euthanasia procedure for small-sized tropical fishes. Brazilian Journal of Biology, 77: 444-450.

Forsberg, B.R.; Melack, J.M.; Dunne, T.; Barthem, R.B.; Goulding, M.; Paiva, R.C.; Sorribas, M.V.; Silva JR, U.L.; Weisser, S. 2017. The potential impact of new Andean dams on Amazon fluvial ecosystems. PLoS One, 12: e0182254.

Foubert, A.; Lecomte, F.; Legendre, P.; Cusson, M. 2018. Spatial organisation of fish communities in the St. Lawrence River: a test for longitudinal gradients and spatial heterogeneities in a large river system. Hydrobiologia, 809: 155-173.

Fukushima, M.; Kameyama, S.; Kaneko, M.; Nakao, K.; Ashley Steel, E. 2007. Modelling the effects of dams on freshwater fish distributions in Hokkaido, Japan. Freshwater Biology, 52: 1511-1524.

Fullerton, A.H.; Burnett, K.M.; Steel, E.A.; Flitcroft, R.L.; Pess, G.R.; Feist, B.E.; Torgersen, C.E.; Miller, D.J.; Sanderson, B.L. 2010. Hydrological connectivity for riverine fish: measurement challenges and research opportunities. Freshwater Biology, 55: 2215-2237.

Giraudoux, P.; Antonietti, J.P.; Beale,C.; Pleydell, D.; Treglia, M. 2018. pgirmess: Spatial analysis and data mining for field ecologists. R package version, 1(9).

Griffiths, D. 2006. Pattern and process in the ecological biogeography of European freshwater fish. Journal of Animal Ecology, 75: 734-751.

Hayashi, M.; Vogt, T.; Mächler, L.; Schirmer, M. 2012. Diurnal fluctuations of electrical conductivity in a pre-alpine river: Effects of photosynthesis and groundwater exchange. Journal of Hydrology, 450: 93-104.

Henriques-Silva, R.; Lindo, Z.; Peres-Neto, P.R. 2013. A community of metacommunities: exploring patterns in species distributions across large geographical areas. Ecology, 94: 627-639.

Henriques-Silva, R.; Logez, M.; Reynaud, N.; Tedesco, P.A.; Brosse, S.; Januchowski-Hartley, S.R.; Oberdorff, T.; Argillier, C. 2019.
A comprehensive examination of the network position hypothesis across multiple river metacommunities. Ecography, 42: 284-294.

Hervé, M. 2020. RVAideMemoire: Testing and Plotting Procedures for Biostatistics. (https://cran.r-project.org/web/packages/ RVAideMemoire). Accessed on 15 Jun 2020.

Lamouroux, N.; Olivier, J.M.; Persat, H.; PouilLy, M.; Souchon, Y.; Statzner, B. 1999. Predicting community characteristics from habitat conditions: fluvial fish and hydraulics. Freshwater Biology, 42: 275-299.

Lapointe, N.W.; Corkum, L.D.; Mandrak, N.E. 2006. A comparison of methods for sampling fish diversity in shallow offshore waters of large rivers. North American Journal of Fisheries Management, 26: 503-513.

Legendre, P.; Legendre, L. 2012. Numerical Ecology. 2nd ed. Elsevier, Amsterdam. 865p.

Legendre, P. 1993. Spatial autocorrelation: trouble or new paradigm? Ecology, 74: 1659 -1673.

Legendre, P; Gallagher, E.D. 2001. Ecologically Meaningful Transformations for Ordination of Species Data. Oecologia, 129: 271-80.

Legendre, P.; Borcard, D.; Peres-Neto, P.R. 2005. Analyzing beta diversity: partitioning the spatial variation of community composition data. Ecological Monographs, 75: $435 \mathrm{e} 450$.

Lourenço, L.S.; Fernandes, I.M.; Penha, J.; Mateus, L.A. 2012. Persistence and stability of cichlid assemblages in neotropical floodplain lagoons. Environmental Biology of Fishes, 93: 427-437.

Lowe-McConnell, R.H. 1999. Estudos Ecológicos de Comunidades de Peixes. Universidade de São Paulo, São Paulo, 535p.

Lucas, M.C.; Batley, E. 1996. Seasonal movements and behaviour of adult barbel Barbusbarbus, a riverine cyprinid fish: implications for river management. Journal of Applied Ecology, 33: 1345-1358.

Niemistö, J.; Holmroos, H.; Horppila, J. 2011. Water pH and sediment resuspension regulating internal phosphorus loading in a shallow lake-field experiment on diurnal variation. Journal of Limnology, 70: 3-10.

Nobile, A.B.; Cunico, A.M.; Vitule, J.R.; Queiroz, J.; VidottoMagnoni, A.P.; Garcia, D.A., et al. 2020. Status and recommendations for sustainable freshwater aquaculture in Brazil. Reviews in Aquaculture, 12: 1495-1517.

Oksanen, J.; Blanchet, F.G.; Kindt, R.; Friendly, R. K.; Legendre, P.; McGlinn, D.; Minchin, P.R.; O’hara, R.B.; Simpson, G.L.; Solymos, P.; Stevens, M.H.H.; Szoecs, E. Wagner, H. 2013. Vegan: Community ecology package, R package version 2.5-6.

Peres-Neto, P.R.; Legendre, P.; Dray, S.; Borcard, D. 2006. Variation partitioning of species data matrices: estimation and comparison of fractions. Ecology, 87: 2614-2625.

Peres-Neto, P.R.; Legendre, P. 2010. Estimating and controlling for spatial structure in the study of ecological communities. Global Ecology and Biogeography, 19: 174-184.

Petry, P.; Bayley, P.B.; Markle, D.F. 2003. Relationships between fish assemblages, macrophytes and environmental gradients in the Amazon River floodplain. Journal of Fish Biology, 63: 547-579.

Quadros, M.D.E.; Rizzotto, G.J. 2007. Geologia e recursos minerais do Estado de Rondônia: texto explicativo do mapa geológico e 
de recursos minerais do Estado de Rondônia-escala 1: 1.000. 000. CPRM, Porto Velho. 1p.

Queiroz, L.J.; Torrente-Vilara, G.; Ohara, W.M.; Pires, T.H. S.; Zuanon, J.; Doria, C.R.C. 2013. Peixes do Rio Madeira. v. I, II, III. Santo Antônio Energia, São Paulo. 1172p.

Rahel, F.J. 1984. Factors structuring fish assemblages along a bog lake successional gradient. Ecology, 65: 1276-1289.

Reis, R.M.; Lourenço, L.S.; Silva, H.P.;Vendrusclo, J; Fernandes I.M. 2020. Length-weight relationships and condition factor of the predatory fish, Cichla pleiozona and Serrasalmus rhombeus, from two tropical reservoirs, Amazon basin, Brazil. International Journal of Fisheries and Aquatic Studies, 8: 355-360

Rodriguez Iturbe, I.; Muneepeerakul, R.; Bertuzzo, E.; Levin, S.A.; Rinaldo, A. 2009. River networks as ecological corridors: A complex systems perspective for integrating hydrologic, geomorphologic, and ecologic dynamics. Water Resources Research, 45: W01413.

R Core Team R. 2020. R: A language and environment for statistical computing. Vienna, Austria: R Foundation for Statistical Computing. R version 3.6.1, (https://www.R-project.org/). Accessed on 15 Jun 2020.

Santos, R.E.; Pinto-Coelho, R.M.; Fonseca, R.; Simóes, N.R.; Zanchi, F.B. 2018. The decline of fisheries on the Madeira River, Brazil: The high cost of the hydroelectric dams in the Amazon Basin. Fisheries Management and Ecology, 25: 380-391.

Scandolara, J.E.; Rizzotto, G.J.; Bahia, R.B.C.; Quadros, M.L.E.S.; Amorim, J.L.; Dall'Igna, L.G. 1999. Geologia e Recursos Minerais do Estado de Rondônia: texto explicativo e mapa geológico na escala 1: 1.000. 000. Programa Levantamentos Geológicos Básicos do Brasil. CPRM-Serviço Geológicos do Brasil, Brasília, 142p.

Shao, X.; Fang, Y.; Jawitz, J.W.; Yan, J.; Cui, B. 2019. River network connectivity and fish diversity. Science of the Total Environment, 689: 21-30.

Siegel, S; Castellan, N.J. 1988. Non parametric statistics for the behavioural sciences. 2nd ed. MacGraw Hill Int., New York. 399p.

Sokal, R.R.; Rohlf, F.J. 1995. Biometry. WH Freeman and Co. New York, 880p.
Swanson, H.K.; Johnston, T.A.; Schindler, D.W.; Bodaly, R.A.; Whittle, D.M. 2006. Mercury bioaccumulation in forage fish communities invaded by rainbow smelt (Osmerus mordax). Environmental Science \& Technology, 40: 1439-1446.

Tonkin, J.D.; Bogan, M.T.; Bonada, N.; Rios-Touma, B.; Lytle, D.A. 2017. Seasonality and predictability shape temporal species diversity. Ecology, 98: 1201-1216.

Torrente-Vilara, G.; Zuanon, J.; Leprieur, F.; Oberdorff, T.; Tedesco, P.A. 2011. Effects of natural rapids and waterfalls on fish assemblage structure in the Madeira River (Amazon Basin). Ecology of Freshwater Fish, 20: 588-97.

Vannote, R.L.; Minshall, G.W.; Cummins, K.W.; Sedell, J.R.; Cushing, C.E. 1980. The river continuum concept. Canadian journal of fisheries and aquatic sciences, 37: 130-137.

Vitorino Júnior, O.B.; Fernandes, R.; Agostinho, C.S.; Pelicice, F.M. 2016. Riverine networks constrain $\beta$-diversity patterns among fish assemblages in a large Neotropical river. Freshwater Biology, 61: 1733-1745.

Ward, J.V.; Stanford, J.A. 1995. The serial discontinuity concept: extending the model to floodplain rivers. Regulated Rivers: Research \& Management, 10: 159-168.

Winemiller, K.O.; McIntyre, P.B.; Castello, L.; Fluet-Chouinard, E.; Giarrizzo, T.; Nam, S.; Stiassny, M. L.J. 2016. Balancing hydropower and biodiversity in the Amazon, Congo, and Mekong. Science, 351: 128-129.

Wurts, W.A.; Durborow, R.M. 1992. Interactions of $\mathrm{pH}$, carbon dioxide, alkalinity and hardness in fish ponds. Southern Regional Acquaculture Center, SRAC Publication no. 464, 4p.

Zar, J.H. 1999. Biostatistical Analysis. Prentice-Hall, New Jersey. $634 \mathrm{p}$.

Zuur, A.F.; Ieno, E.N.; Elphick, C.S. 2010. A protocol for data exploration to avoid common statistical problems. Methods in Ecology and Evolution, 1: 3-14.

RECEIVED: 01/06/2020

ACCEPTED: $11 / 03 / 2021$

ASSOCIATE EDITOR: Cristhiana Röpke 